\title{
NETWORK-CENTRIC CONTROL TECHNOLOGY OF DATA TRANSFER BY NETWORK COMMUNICATIONS
}

\author{
S.V. Melnikov, A.E. Volkov, N.N. Komar, D.A. Voloshenyuk
}

\begin{abstract}
International Research and Training Center for Information Technologies and Systems, Kyiv, Ukraine

Рассмотрен вопрос необходимости проведения компьютерного моделирования современных сетевых коммуникаций и использования новых моделей и интеллектуального управления в целях повышения безопасности и качества работы сети передачи данных и связи, особенно в сложных условиях.

Ключевые слова: сетецентрическая система, управляющие технологии, сеть, компьютерное моделирование, виртуальные модели.
\end{abstract}

\section{INTRODUCTION}

Last year's around the world there is a rapid growth of wireless data networks used in the scale of individual enterprises (LANs), and as a binder component for corporate and government networks. A powerful incentive to this growth - the emergence of new standards regulating the operation of wireless networks [1].

The problem of increasing network performance is very relevant. In practice, the actual speed of data transmission / receiving is significantly lower than the bit rate supported by used network technology. Particularly this problem is acute in wireless networks. The actual wireless network bandwidth depends on the used technology, the number of subscribers in the network, length and quality of communication channels, electromagnetic interference, weather, network equipment, protocols and many other factors.

At the present time the development of motion control systems of dynamic objects is based on the using of navigation telecommunications networks, in which are widely used satellite navigation technology and communications, together with the network technologies of navigation information transmission. This combination of hardware and software makes it possible to ensure the optimum performance of navigation equipment and allows to implement the multivariable modeling techniques in navigational and communication networks using complex databases of characteristics of different types dynamic objects. Digital communication and information technologies are crucial for the implementation of network-centric control of air, sea and ground objects based on the joint use of the navigation information on the basis of common interfaces, standards and protocols.

\section{STATEMENT OF PROBLEM}

Formulation of the research problem is the need to develop the technologies for control of communication process between all network objects and technology for management of data information transfer in models of remote control in distributed networks [2]. 
The main factor affecting the performance of computer networks is a network delay in the transmission of data packets. Previous studies have shown that the use of the existing scientific and technical solutions in the computer networks of distributed control of applied process does not provide required quality of control and management of data transmission at presence of packet delay in the network.

For example, at influence of electromagnetic interference the transmitted information is distorted. This fact is detected by analyzing the checksum of the network packet. If the packet has been distorted, he discarded by the receiver. As a result, the receiver does not send a confirmation of successful reception to the transmitter, and, consequently, the sender retransmits the packet. Thus, the longer the packet and the higher the probability of bit error, the smaller the performance of a computer network.

Scientific novelty of idea is the use of net-centric technology to develop advanced control systems for data information transfer. It should be noted that under net-centric technology we mean such structure of the remote control, which provides interconnection of network elements, the ability of interaction between them and the management of them in real time. This will ensure a functional and timing compatibility of all network elements [3].

Purpose of the work is to explore the fundamentals and principles of construction of new and perspective control systems for transfer of information and communication data in network using the net-centric technology. It will significantly expand the list of solved tasks of distributed control of high-speed cycles of application processes and improve the quality, reliability and security of network systems in general.

Purpose and objectives of the work is to get a basis for further research and practical development of technologies for monitoring and management of application processes in the network in real time scale based on net-centric technologies that will improve the quality, reliability and security of network systems and technologies.

\section{NETWORK-CENTRIC CONTROL TECHNOLOGY OF DATA TRANSFER BY NETWORK COMMUNICATIONS}

In the early years of the appearance of communication between computers software for networking was created haphazardly, for each individual case. After the networks gained enough popularity, the majority of experts recognized the need for standardization of software and hardware of computer networks. It is obvious that standardization enables system vendors to develop hardware and software that will be able to operate even in the presence of different architectures.

It is necessary to draw a clear line between the work of software and hardware components of network. There is diverse equipment that operates in the network; its performance and reliability are dependent on this equipment. Other network characteristics, such as transparency and safety depend on a variety of software: network operating systems and network applications. 
The network is the connection of different equipment, different software, and therefore the problem of compatibility of different technologies and equipment of various types of operating systems remains important.

Of course, there is a certain independence of operation of hardware and software, which together perform the work of a computer network. This independence laid in a common unified system of construction of the network components. Software tools "do not muse about" what happens on "lower layer" of the network, they simply send their requests over there and receive a response in the form understandable for themselves. In its turn the network hardware resources "do not muse about" what the software does with the result of their work, they receive a request, perform the necessary actions and provide an answer.

Without the generally accepted standards of construction of network equipment, progress in network development in such a huge variety of networking products, would be simply impossible.

Until recently, developers of network equipment concentrated their attention mainly on the problems of transferring information packets in computer networks, but now many leading companies (IBM, Intel, HP, EMC, Microsoft, Motorola, Symantec, Siemens, Boeing, Honeywell and many others) develop specialized software and hardware solutions for net-centric distributed control systems. The use of existing technical solutions (patents US6683889-Siemens, EP1661343-Motorola, US6363056-Ibm, WO0237773-Intel, EP1426870-Boeing, US2007111725-Honeywell and others) in computer networks of distributed control of high-speed cycles of application process does not provide required quality of control [4].

Analysis of recent research, literature and patent searches on this issue show a high relevance of submitted question and the need to resolve it. In particular, the 2013-2028 Global Air Navigation Plan of International Civil Aviation Organization envisages improvement of air navigation service due to control and management of the transfer of digital aeronautical information, which coincides with direction of our work [5].

The project is based on applied research in the field of high-speed cycles control systems for net-centric dynamic application processes with spatiallydistributed interrelated functional components. Thus it provides functional and temporal combination of internal resources of net-centric distributed control systems with objects and technological processes on the basis of shared use of dynamics models working in an accelerated time scale into a single space-time netcentric complex.

An idea of net-centric and neural network technologies for monitoring the quality of data transmission with the wireless network is proposed. The main scientific and technical idea of design of monitoring systems and distributed control systems of a wide class of application processes, namely data transmission in the global expanse of information networks on the basis of network-centric technology consists in forming of commands of distributed control. This is achieved by simulation of dynamics of the application process in accelerated time scale in conjunction with the simulation of the process of formation of control 
commands according to the current condition of the application process. This allows compensating the delays, errors and packet distortions in networks [6].

To conduct the necessary research of communication lines and use of network-centric applications and neural network technologies a method of route control and the quality of information data transfer via Wi-Fi-network was developed. A computer algorithm and software that determine the data route, the parameters of the network, delays and the losses of data packets were developed. Also, this software localizes the point with the highest transmission path delays and losses, and offers an alternative data transmission route with higher quality.

Realization of researches is based on the methods of mathematical analysis, combinatorial optimization, probability theory, simulation, automatic control theory, methods of nonlinear absolute invariance and software packages, such as, MatLab Simulink, C++ programming language, Adobe Flash and others.

There is an example of the practical results obtained by the analyzing of network quality on Figure 1. The graph shows the time-relation of data transmission and receiving speed with different number of users.

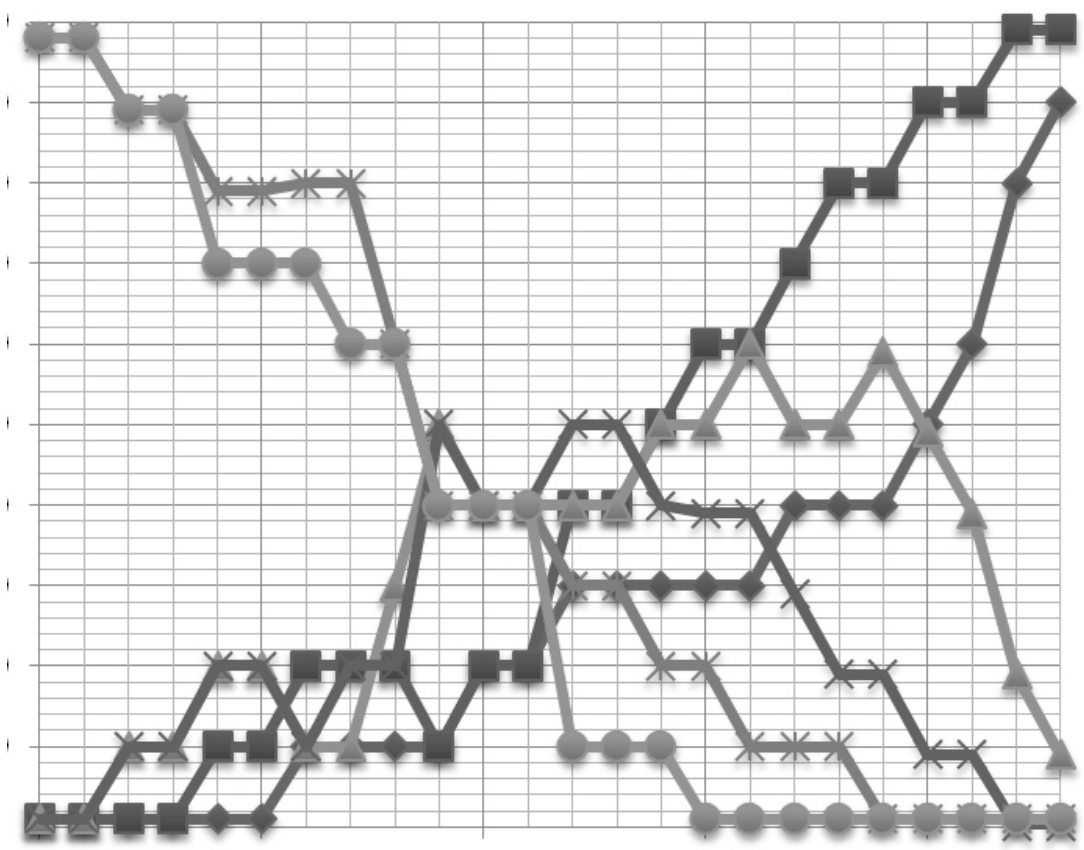

Fig. 1. Time-relation of data transmission and receiving speed with different number of users

To solve the problem of determining the quality of the data transfer process in order to further control and manage this process, a method which is based on software that works with any standardized computing environment was developed. This method detects and evaluates the operating parameters of the wired Internet network before, during and after transmission of the information data packets provides analytical (numerical values of time delay of packet transmission, the percentage of lost data, signal quality, transmission speed and receive speed) and graphic parameters to control information transmission routes (Fig. 2, Fig. 3 and Fig. 4). 


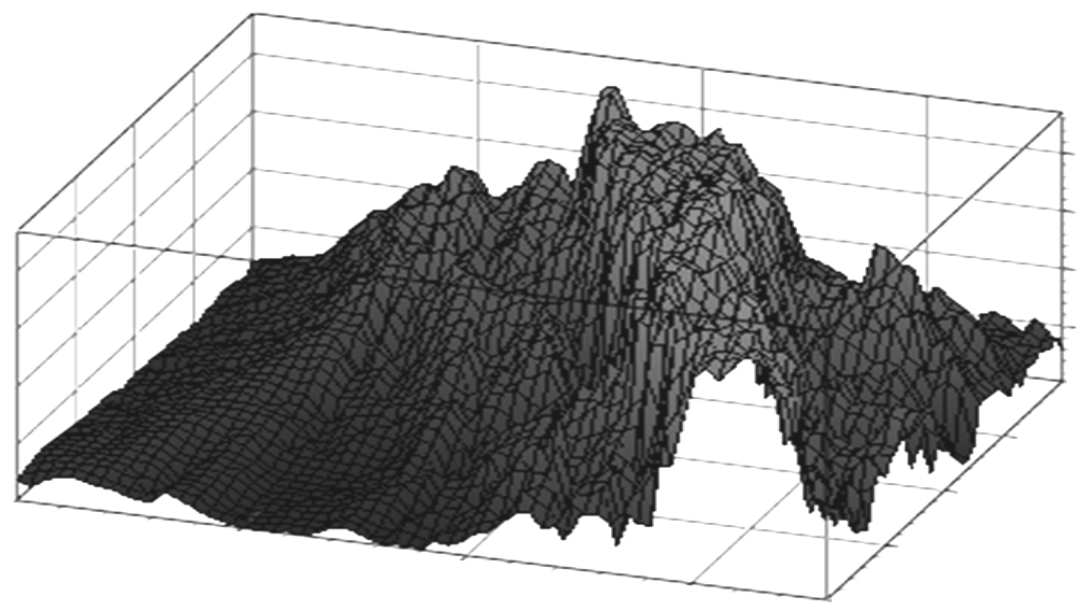

Fig. 2. The graph of signal-to-noise ratio while removing the transmitter from the source of interference

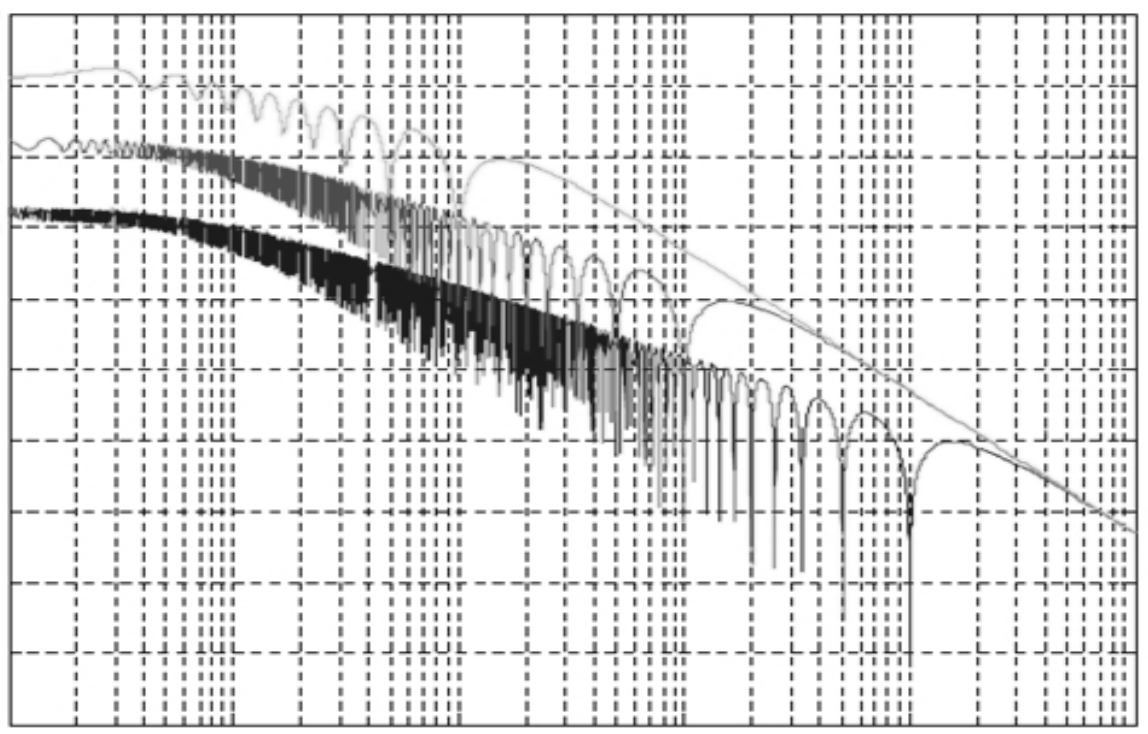

Fig. 3. Signal strength depending on the frequency and distance of data transmit

Executing of a method is provided by connection to any wired Internet network with arbitrary parameters. The collected data is stored in a computer environment for further processing and collection of statistical data. Based on these data the possibility of using different ways to compensate time delays and loss of data packets in the network was considering (Fig. 5), there is a practical possibility of using methods of compensation based on the data transmission systems with feedback what is implemented in the present method. A characteristic feature of this method is that the decision to re-transfer and use of compensation protocols is accepted in the final destination (by receiver). 


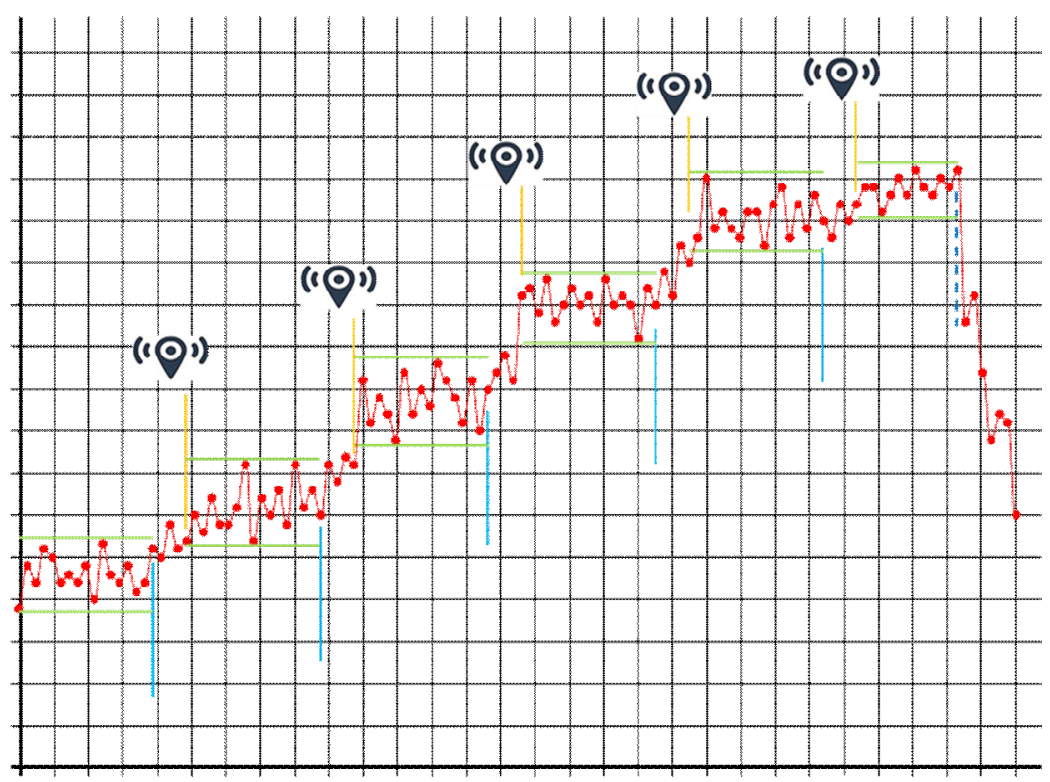

Fig. 4. The dependence of signal power on the number of parallel transmission sources

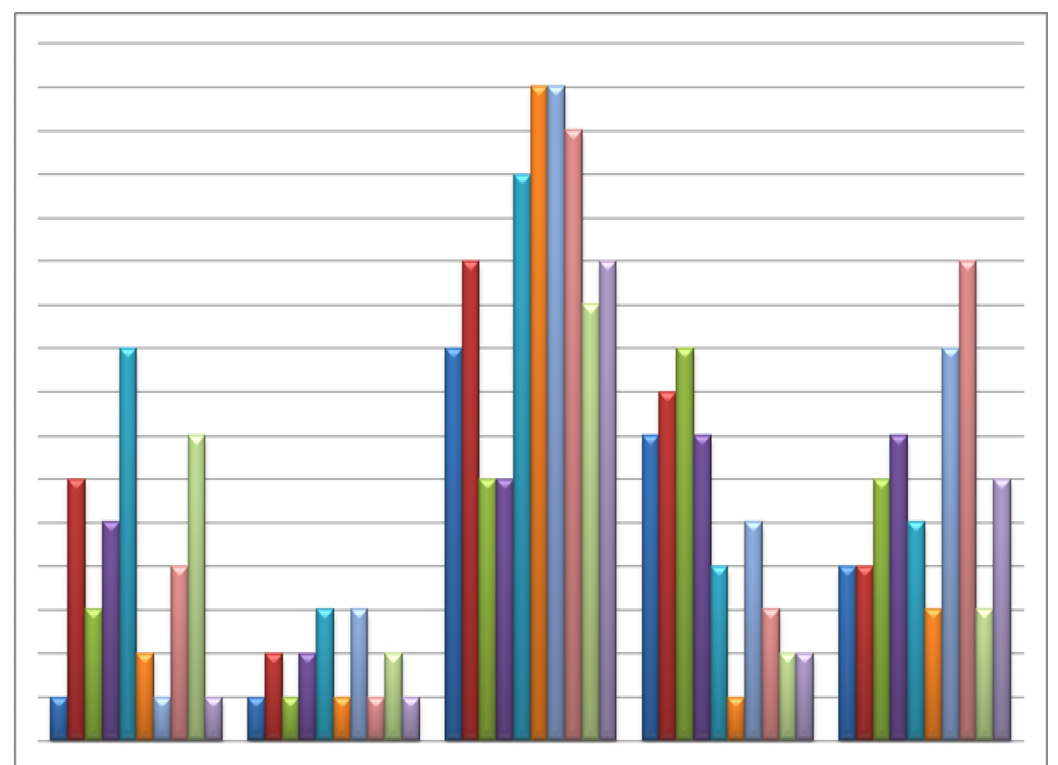

Fig. 5. The graph transmission numbers of fragments of one file (10 broken fragments) at 5 network transfers

Result of data transfer simulations with using network-centric system which is based on the method of control of the quality of information data transfer via a wired Internet connection showed that the results of the quality of network performance is almost in 3 times better than standard network connection. This confirms the appropriateness of using the given development in the terrestrial wired data transmission systems and the need to develop such technology for wireless connection.

(C) S.V. Melnikov, A.E. Volkov, N.N. Komar, D.A. Voloshenyuk, 2016

ISSN 2519-2205 (Online), ISSN 0454-9910 (Print). Киб. и выч. техн. 2016. Вып. 186. 
Development of modern intelligent automated control systems of dynamic objects and processes in a distributed environment should be based on high-speed data transfer technologies. For the high mobility of these intelligent systems it is important to use wireless technology. This will allow to create a new adaptive network-centric principles of intelligent control. Weaknesses of the modern wireless data transmission technologies (e.g., Bluetooth, and Wi-Fi) are crucial for the construction of such intelligent control. High sensitivity to time delays, obstructions, interference and noise makes it difficult to create high quality intelligent systems. Thus, the development of new algorithms and methods for improving the quality of modern communication systems and communication is one of the priority directions in the field of intelligent control.

\section{CONCLuSions}

It may be noted that the problem of the need to create a net-centric management and control system of transmission of information data in a remote control models of dynamic objects (in our case, aircraft) has a high priority and actuality, that is confirmed by the ICAO's 2013-2028 Global Air Navigation Plan.

The paper proposes the idea of using net-centric technologies that will provide a new opportunity to control dynamic objects in real time.

Considering and taking as a basis the problem of the quality of the wireless network and the need to improve the transition by using new principles and technologies of data transmission, the method of control and determine the quality of information data transfer via a wired Internet connection was developed. This method allows: to determine the data route via the Internet and the network settings, delays and loss of data packets (Fig. 4); to localize the point of transmission of the route with highest delays and losses; to provide an alternative data transmission route with better quality. This method was developed as a basis for net-centric management and control system of transmission of information data in the models of remote control of aircraft.

Experiments and simulations of the use of such a system are shown that:

- obtained delays, as well as the loss or corruption of data, significantly higher than aviation tolerances, which confirms the relevance of this work;

- the use of the developed method improves the quality of modeling process for linear regression models;

- it is possible to extrapolate and approximate output signals which have rather complicated forms;

- both linear and nonlinear dynamic models are taken into account;

- it opens the way for creation of new ways and methods for compensation and prevention of network errors, delays, distortions, interferences and packet loss of information data;

- development a method for determining the quality of information data transmission via a wireless connection, also as a creating programs for protection against unauthorized network access - are a perspective research objectives.

- for the effective functioning of control systems with distributed information and executive resources in heterogeneous navigation networks, in case 
of the using of remote control system it is necessary to complex consideration of all the control processes elements and accounting of the following recommendations:

- the distribution of control information on the importance relative to the management objectives and acceptable delays in transmission;

- defining of specifications of protocols for data transfer for the various types of information;

- determination of the feasibility of using different channels and information transmission routes;

- ranking priorities of the importance of the data and its transmission sequence in information structures;

- the creation of structures that duplicate the data transfer process;

- determination of the structure of the distribution of parts of the system depending on the possible delay interval of control signal.

Furthermore additional features of control structures organization which take into account the developed methods of control of high-speed dynamic processes can be used.

1. Мизин И.А., Уринюк Л.С., Храмешин Г.К. Передача информации в сетях с коммутацией сообщений. М.: Связь, 1977. 328 с.

2. Павлова С.В., Богачук Ю. П., Мельников С. В. Моделирование технологии распределенного сетевого управления летательными аппаратами. КBT. 2011. Вып. 163. C. $45-53$.

3. Спосіб контролю маршруту та визначення якості процесу передачі інформаційних даних через дротову Інтернет-мережу: пат. 04108 Україна: МПК(2013) G06N 7/00. Заявл. 15.05.2014; опубл. 16.07.2014. - 9 с.

4. Харченко В.П. Креденцар С. М. Мережі та бази даних. НАУ. Киев, 2013. - 328 с.

5. Глобальный аэронавигационный план на 2013-2028 года. Пропускная способность и эффективность. Международная организация гражданской авиации ИКАО. Монреаль, Канада. 2013. Вып. 4. 128 с.

6. Паук С.М. Сети авиационной электросвязи. М.: Транспорт, 1986. 271 с.

UDK 681.518

\title{
NETWORK-CENTRIC CONTROL TECHNOLOGY OF DATA TRANSFER BY NETWORK COMMUNICATIONS
}

\author{
S.V. Melnikov, A.E. Volkov, N.N. Komar, D.A. Voloshenyuk \\ International Research and Training Center for Information Technologies and \\ Systems, Kyiv, Ukraine
}

Introduction. The problem of increasing network performance is very relevant. In practice, the actual speed of data transmission / receiving is significantly lower than the bit rate supported by used network technology. The actual wireless network bandwidth depends on the used technology, the number of subscribers in the network, length and quality of communication channels, electromagnetic interference, weather, network equipment, protocols and many other factors. 
The purpose. The project is based on applied research in the field of highspeed cycles control systems for net-centric dynamic application processes with spatially-distributed interrelated functional components. Thus it provides functional and temporal combination of internal resources of net-centric distributed control systems with objects and technological processes on the basis of shared use of dynamics models working in an accelerated time scale into a single space-time net-centric complex.

Results. To solve the problem of determining the quality of the data transfer process in order to further control and manage this process, a method which is based on software that works with any standardized computing environment was developed. This method detects and evaluates the operating parameters of the wired Internet network before, during and after transmission of the information data packets provides analytical (numerical values of time delay of packet transmission, the percentage of lost data, signal quality, transmission speed and receive speed) and graphic parameters to control information transmission routes. This paper provides the results of computer simulation which are represent the network connection quality.

Conclusion. Development a method for determining the quality of information data transmission via a wireless connection, also as a creating programs for protection against unauthorized network access - are a perspective research objectives. Results of simulations confirm the appropriateness of using the given method of data transfer control in the terrestrial wired data transmission systems and the need to develop such technology for wireless connection.

Keywords: network-centric; control technology; communication; computer modeling; virtual model.

1. A.A. Mizin Transmission of information via circuit-switched communications networks. M.: Communications, 1977. 328 p.

2. S.V. Pavlova, Y.P. Bogachuk, S.V. Melnikov Simulation technology of distributed network of aircraft control. Cybernetics and Computer Science. 2011. Vol. 163. pp. 45-53.

3. Method of control of the route and determine the quality of the transfer of information data through a wired Internet network, Patent of Ukraine №04108, IPC (2013) G06N 7/00, stated 15/05/2014, Published 07/16/2014.

4. V.P. Kharchenko, S.M. Kredentsar Networks and databases. NAU. Kiev, 2013. 328 p.

5. 2013-2028 Global Air Navigation Plan. The capacity and effectiveness. International Civil Aviation Organization ICAO. Montreal, Canada, 2013. Vol. 4. 128 p.

6. S.M. Pauk Aeronautical Telecommunication Networks. M.: Transport, 1986. 271 p.

УДК 681.518

\title{
МЕРЕЖЕЦЕНТРИЧНА ТЕХНОЛОГІЯ КОНТРО- ЛЮ ПЕРЕДАЧІ ДАНИХ У МЕРЕЖІ
}

\author{
Мельников С.В., Волков О.С., Комар М.М., Волошенюк Д.О. \\ Міжнародний науково-навчальний центр інформаційних технологій та систем \\ НАН Украӥни та МОН Украӥни, Киӥв, Украӥна
}

Вступ. Проблема підвищення продуктивності комп'ютерної мережі досить актуальна. На практиці реальна швидкість прийому / передачі даних виявляється істотно нижче, ніж бітова швидкість, підтримувана 
використовуваною мережевою технологією. Особливо гостро ця проблема постає в бездротових мережах. Реальна пропускна здатність бездротової комп'ютерної мережі залежить від використовуваної технології, кількості абонентів в мережі, протяжності і якості каналів зв'язку, рівня електромагнітних завад, погоди, використовуваного мережевого обладнання, протоколів та багатьох інших факторів. Постановка досліджуваної проблеми полягає у необхідності розробки технологій контролю за процесом зв'язку між усіма об'єктами мережі та технології управління передачею даних в моделях віддаленого керування у розподілених мережах.

Мета роботи - дослідити фундаментальні основи та принципи побудови нових перспективних систем контролю передачі інформаційнокомунікаційних даних в мережі на основі застосування мережецентричних технологій, що дозволить істотно розширити перелік вирішуваних в реальному масштабі часу задач розподіленого керування швидкісними циклами прикладних процесів та підвищити якість, надійність та безпеку роботи мережевих систем взагалі.

Одержані результати. В основу проекту покладені прикладні дослідження в галузі керування системою швидкісних прецизійних циклів мережецентричних динамічних прикладних процесів 3 простороворозподіленими взаємозв'язаними інформаційними i функціональними компонентами. При цьому забезпечується функціонально-часове поєднання внутрішніх ресурсів мережецентричних систем розподіленого керування 3 об'єктами та технологічними процесами на базі сумісного використання працюючих в прискореному масштабі часу моделей динаміки в єдиний просторово-часовий мережецентричний комплекс. Основна науково-технічна ідея побудови систем контролю та розподіленого управління широким класом прикладних процесів, а саме передачею даних, полягає у формуванні команд розподіленого управління шляхом моделювання в прискореному масштабі часу динаміки прикладного процесу спільно 3 моделюванням процесу формування команд управління.

Висновки. 3 огляду на і беручи за основу проблему якості роботи бездротової мережі і необхідність їі поліпшення переходом на нові принципи i технології передачі даних, був розроблений спосіб контролю маршруту і визначення якості передачі інформаційних даних через дротовий Інтернетзв'язок, що дозволяє: визначити маршрут передачі даних через Інтернет, параметри роботи мережі, затримки і втрати пакетів даних; локалізувати точку маршруту передачі 3 найбільшими затримками і втратами; надати альтернативний, більш якісний, маршрут передачі даних.

Ключові слова: мережецентрична система, безпека польотів, інваріантність, конфліктні ситуації, диференціальні ігри, вільний політ.

Получено 28.11.16 